\title{
Arsenic trioxide induces autophagy and antitumor effects in Burkitt's lymphoma Raji cells
}

\author{
CAI-LI LI ${ }^{1,2}$, HU-LAI WEI ${ }^{1}$, JING CHEN $^{1}$, BEI WANG ${ }^{1}$, BEI XIE ${ }^{1}$, \\ LIN-LAN FAN ${ }^{1}$ and LIN-JING LI ${ }^{1}$ \\ ${ }^{1}$ Key Laboratory of Preclinical Study for New Drugs of Gansu Province, School of \\ Basic Medical Sciences, Lanzhou University, Lanzhou, Gansu 730000; ${ }^{2}$ School of Medicine \\ of Northwest University For Nationalities, Lanzhou, Gansu 730030, P.R. China
}

Received April 2, 2014; Accepted June 11, 2014

DOI: $10.3892 /$ or.2014.3369

\begin{abstract}
Although it is generally acknowledged that autophagy plays an important role in tumorigenesis and therapy, studies of autophagy in different cell types and under different conditions have led to conflicting theories regarding the influence of autophagy on cell death. In the present study, we explored the role of autophagy and its underlying mechanism in the inhibitory effects of arsenic trioxide $\left(\mathrm{As}_{2} \mathrm{O}_{3}\right)$ on Burkitt's lymphoma Raji cells. The results showed that $\mathrm{As}_{2} \mathrm{O}_{3}$ significantly inhibited the proliferation of Raji cells in a dose- and time-dependent manner, induced $\mathrm{G} 2 / \mathrm{M}$ phase cell cycle arrest and apoptosis. Moreover, $\mathrm{As}_{2} \mathrm{O}_{3}$ also promoted the formation of autophagic vacuoles, as well as increased the degradation of autophagy substrate P62 protein, which was accompanied by an upregulation of Beclin-1 gene and a downregulation of Bcl-2 gene expression. 3-Methyladenine, an autophagy inhibitor, not only increased cell viability through inhibiting autophagic cell death and apoptosis, but also reversed the upregulation of Beclin-1 gene and the downregulation of Bcl-2 gene in the Raji cells induced by $\mathrm{As}_{2} \mathrm{O}_{3}$. These results may lead to a better understanding of the action of $\mathrm{As}_{2} \mathrm{O}_{3}$ and may provide evidence that autophagy plays an important role in the regulation of cell death. Therefore, regulation of autophagic activity may be a promising therapy for patients with Burkitt's lymphoma.
\end{abstract}

\section{Introduction}

Burkitt's lymphoma originates from follicular germinal centers, it is the high-grade malignant B cell lymphoma. Efforts are ongoing to develop innovative and effective therapies. An

Correspondence to: Professor Hu-Lai Wei, Key Laboratory of Preclinical Study for New Drugs of Gansu Province, Lanzhou University, 199 Donggang West Road, Lanzhou, Gansu 730000, P.R. China

E-mail: weihulai@lzu.edu.cn

Key words: apoptosis, arsenic trioxide, autophagy, Burkitt's lymphoma, 3-methyladenine important part of this process is to understand the mechanism of cell death induced by potential chemotherapeutic agents.

Autophagy is a tightly regulated catabolic process whereby cells degrade their own components by enveloping them in double-membrane vesicles referred to as autophagosomes and targeting them for lysosomal degradation. Furthermore, it plays an important role in tumorigenesis and therapy (1). Studies of autophagy in different cell types and under different conditions have provided conflicting results regarding the influence of autophagy on cell death $(2,3)$. Autophagy is activated during environmental stress, such as nutrient starvation or hypoxia, thereby promoting cell survival; however, hyperactive autophagy seriously disturbs the coordination of cell metabolism and finally causes cell death, known as autophagic cell death or type II programmed cell death (type II PCD) $(4,5)$. Autophagic cell death is a caspase-independent cell death pattern, which is different from apoptosis (type I PCD). However, recent reports suggest that autophagy and apoptosis often share similar effectors and regulators and a complex crosstalk exists between the two processes (6).

Arsenic trioxide $\left(\mathrm{As}_{2} \mathrm{O}_{3}\right)$ has been used successfully in the treatment of patients with newly diagnosed acute promyelocytic leukemia (APL) $(7,8)$. It has also been reported that $\mathrm{As}_{2} \mathrm{O}_{3}$ can also be used for treating other hematological malignancies and solid tumors (9-11). Numerous studies have demonstrated that the antitumor mechanism of $\mathrm{As}_{2} \mathrm{O}_{3}$ is very complicated and it may result from causing cell cycle arrest and inducing tumor cell apoptosis (12). However, the detailed mechanisms of $\mathrm{As}_{2} \mathrm{O}_{3}$-mediated cell death are not fully understood. In the present study, we evaluated the role of autophagy and the relationship between autophagy and apoptosis during Raji cell death induced by $\mathrm{As}_{2} \mathrm{O}_{3}$. Our findings may provide a theoretical reference for further study on the antitumor mechanism of $\mathrm{As}_{2} \mathrm{O}_{3}$.

\section{Materials and methods}

Cells and reagents. Burkitt's lymphoma Raji cells were purchased from Shanghai Institute of Biochemistry and Cell Biology (Shanghai, China). $\mathrm{As}_{2} \mathrm{O}_{3}, 3$-methyladenine (3-MA), MTT, RPMI-1640 medium and monodansylcadaverine (MDC) were purchased from Sigma (St. Louis, MO, USA). Fetal 
bovine serum (FBS) was from Sijiqing Biotechnology Co. (Hangzhou, China). The antibodies for caspase-3, Beclin-1, Bcl-2, P62, LC3 and $\beta$-actin were obtained from Cell Signaling Technology (Danvers, MA, USA). All primers for beclin-1, bcl-2 and $\beta$-actin were synthesized by Takara Corporation (Japan) and SYBR Premix Ex Taq and PrimeScript RT reagents were also from Takara. Raji cells were cultured in RPMI-1640 medium with $10 \%$ (v/v) FBS, $100 \mathrm{U} / \mathrm{ml}$ penicillin and $100 \mu \mathrm{g} / \mathrm{ml}$ streptomycin at $37^{\circ} \mathrm{C}$ in the presence of $95 \%$ air, $5 \% \mathrm{CO}_{2}$ with medium changes every 2 days. Cells in the mid-log phase were used in the experiments.

Cell proliferation analysis. Cells were seeded at a density of $5 \times 10^{4}$ cells $/ \mathrm{ml}$ in 96 -well plates. After treatment, cell viability was evaluated by an MTT colorimetric assay. The spectrophotometric absorbance of the sample was measured using a Powerwave X plate reader (Bio-Tek, Winooski, VT, USA) at $570 \mathrm{~nm}$. All samples were carried out in sextuplicate.

Flow cytometric analysis of apoptosis and cell cycle. For detection of $\mathrm{As}_{2} \mathrm{O}_{3}$-induced apoptosis, $10^{6}$ cells were collected and suspended in binding buffer $(400 \mu \mathrm{l})$ and incubated with Annexin V-FITC and propidium iodide (PI) for $0.5 \mathrm{~h}$ and then suspended in binding buffer. The samples were analyzed by flow cytometry (Beckman Coulter, Miami, FL, USA). For cell cycle analysis, $\sim 1 \times 10^{6}$ cells were collected and fixed overnight in $70 \%$ ethanol at $4^{\circ} \mathrm{C}$. Cells were then washed with PBS and stained with PI in the presence of DNase-free RNase. After 30 min incubation at room temperature in the dark, cells within the cell cycle compartments were determined by flow cytometer.

Detection of autophagosome. Cells were fixed with $2 \%$ paraformaldehyde and $2 \%$ glutaraldehyde in $0.1 \mathrm{~mol} / 1$ phosphate buffer ( $\mathrm{pH}$ 7.4), followed by $1 \% \mathrm{OsO}_{4}$. After dehydration, thin sections were stained with uranyl acetate and lead citrate for observation under JEM-1230 transmission electron microscopy (JEOL, Tokyo, Japan).

MDC fluorescent staining. MDC has been proposed as a special tracer for autophagic vacuoles (13). The autophagic vacuoles were labeled with $0.05 \mathrm{mmol} / 1 \mathrm{MDC}$ in $\mathrm{PBS}$ at $37^{\circ} \mathrm{C}$ for $1 \mathrm{~h}$. After incubation, cells were washed with PBS and immediately analyzed by fluorescence microscopy.

Western blot analysis. At the end of the designated treatments, Raji cells were lysed in RIPA lysis buffer (Beyotime, P0013B) with $1 \mathrm{mM}$ PMSF. Equal amounts of protein were separated by SDS-PAGE and transferred onto PVDF membranes. After blocking with $5 \%$ non-fat dried milk in PBS with $0.5 \mathrm{ml} / 1$ Tween-20 for $2 \mathrm{~h}$ at room temperature, the membrane was probed with primary antibodies against human Beclin-1, LC3, $\mathrm{P} 62$, caspase- $3, \mathrm{Bcl}-2$ or $\beta$-actin proteins. Then, the membranes were incubated with the IRDye $800 \mathrm{CW}$ or IRDye700DX conjugate secondary antibodies (LI-COR, Lincoln, NE, USA). The protein bands of immunoblot were visualized by an Odyssey double-color infrared laser imaging system (LI-COR).

Real-time quantitative RT-PCR assay. Total RNA from the cells was extracted using the TRIzol kit. From each sample,
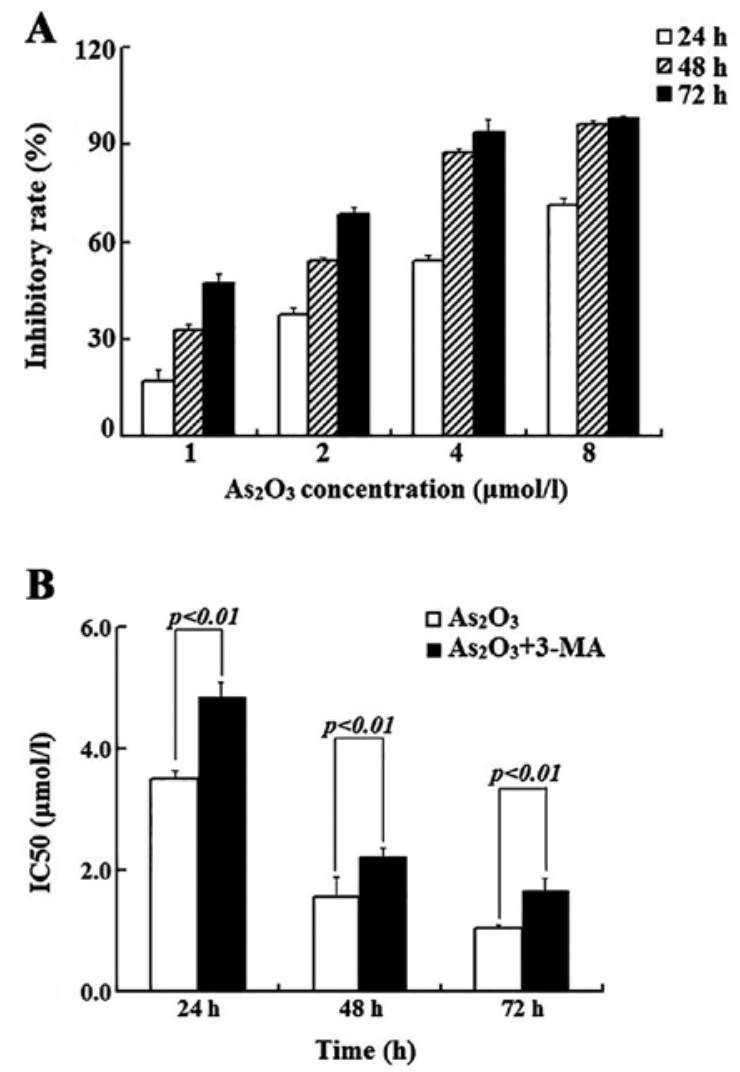

Figure 1. MTT assay was applied for cell proliferation detection. (A) $\mathrm{As}_{2} \mathrm{O}_{3}$ inhibited the viability of Raji cells in a dose- and time-dependent manner. (B) 3-MA reduced $\mathrm{As}_{2} \mathrm{O}_{3}$-induced Raji cell death. ${ }^{* *} \mathrm{P}<0.01$ compared to $\mathrm{As}_{2} \mathrm{O}_{3}$ group. 3-MA, 3-methyladenine.

$2 \mu \mathrm{g}$ of RNA was converted into cDNA by oligo (dT) 18-primed reverse transcription using SuperScript II RT First-Strand kit as described by the manufacturer. The levels of the genes were analyzed on Rotor-Gene 3000 quantitative PCR amplifier (Corbett, Australia).

Statistical analysis. All data are expressed as means \pm SD . Statistical analysis was performed using Student's t-tests and SPSS 13.0. $\mathrm{P}<0.05$ and $\mathrm{P}<0.01$ were considered to indicate a statistically significant and highly statistically significant difference, respectively.

\section{Results}

$\mathrm{As}_{2} \mathrm{O}_{3}$-mediated inhibition of growth and induction of apoptosis in Raji cells. It has been shown that $\mathrm{As}_{2} \mathrm{O}_{3}$ induces growth arrest and apoptosis in many different cancer cell lines. We treated Raji cells with various concentrations $(0-8 \mu \mathrm{mol} / \mathrm{l})$ of $\mathrm{As}_{2} \mathrm{O}_{3}$ for 24,48 and $72 \mathrm{~h}$; the cell numbers were determined and the inhibitory rates are plotted in Fig. 1A. It is clearly shown that the cell growth was inhibited by $\mathrm{As}_{2} \mathrm{O}_{3}$ in a doseand time-dependent manner. In addition, the $\mathrm{IC}_{50}(\mu \mathrm{mol} / \mathrm{l})$ of this agent at 24,48 and $72 \mathrm{~h}$ was calculated as $3.51 \pm 0.13$, $1.57 \pm 0.32$ and $1.03 \pm 0.08$, respectively (Fig. 1B). Since $\sim 50 \%$ of the cell growth was inhibited when the cells were treated with $3 \mu \mathrm{mol} / \mathrm{l}$ of $\mathrm{As}_{2} \mathrm{O}_{3}$ for $24 \mathrm{~h}$, we treated the cells with $\mathrm{As}_{2} \mathrm{O}_{3}$ at this concentration and the results from the flow cytometry showed that when the cells were treated for 24 and $48 \mathrm{~h}$, the 

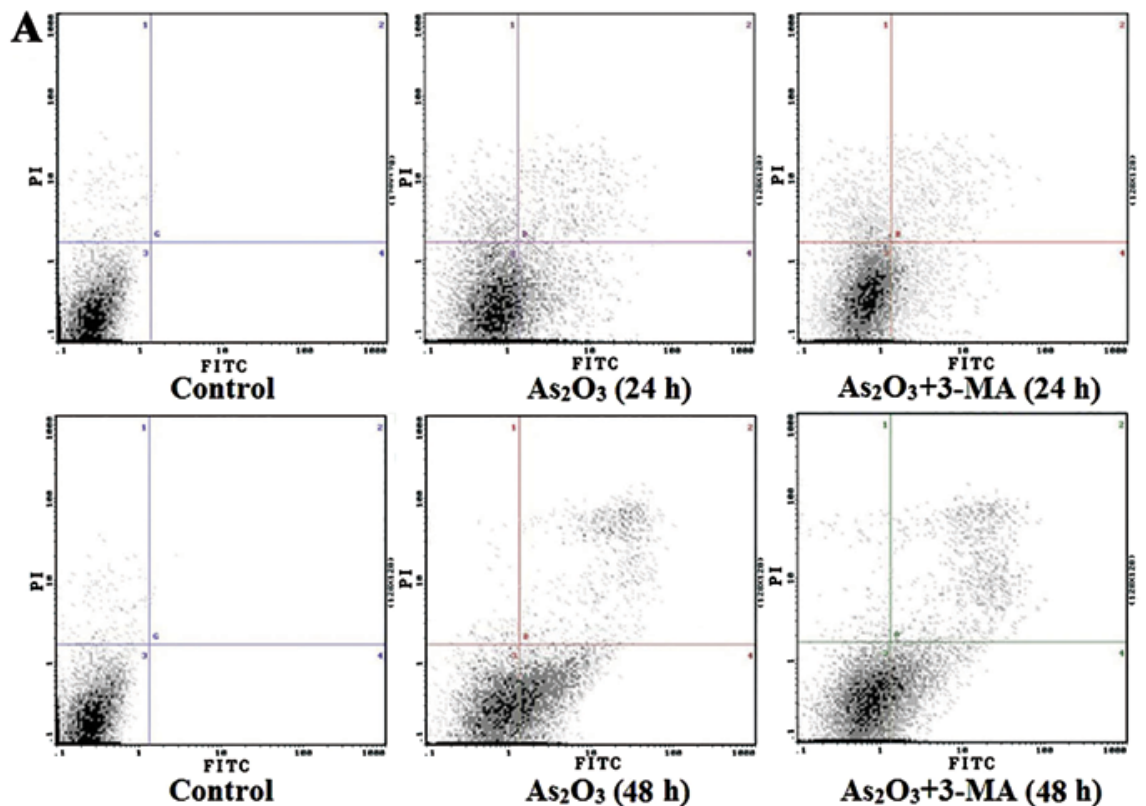

$\mathrm{As}_{2} \mathrm{O}_{3}+3-\mathrm{MATC}(24 \mathrm{~h})$

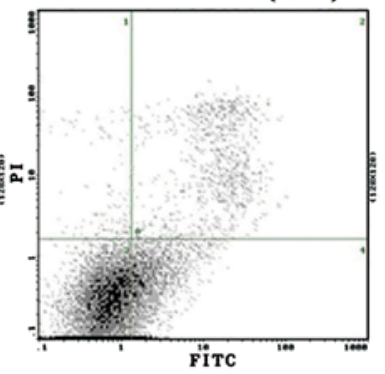

$\mathrm{As}_{2} \mathrm{O}_{3}+3-\mathrm{MA}(48 \mathrm{~h})$

B

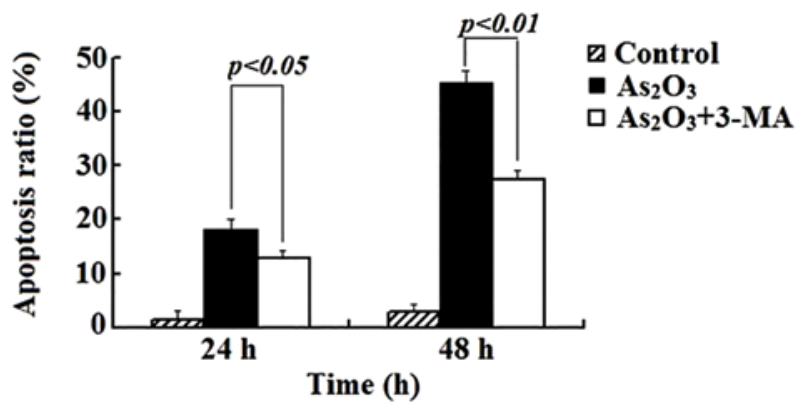

Figure 2. The effect of $\mathrm{As}_{2} \mathrm{O}_{3}$ with or without 3-MA on Raji cell apoptosis. (A) Apoptosis ratio detected by flow cytometry. (B) Histogram of corresponding apoptotic ratios. 3-MA, 3-methyladenine.

apoptotic population increased from $2.72 \pm 1.09$ to $23.5 \pm 1.32$ and $40.8 \pm 2.48 \%$, respectively (Fig. 2). In addition, the percentage of cells on different cell cycle stages was determined by flow cytometry. As shown in Fig. 3, the $\mathrm{As}_{2} \mathrm{O}_{3}$ treatment reduced the population in the G0/G1 phase and increased that in both the $\mathrm{S}$ - and the G2/M-phase. Compared to the control, the cells in the G2/M phase increased from 11.8 to $26.4 \%$ after they were treated with $\mathrm{As}_{2} \mathrm{O}_{3}$ for $48 \mathrm{~h}$. Consistent with the increased apoptotic population shown in the flow cytometry, western blot assays showed the increased intensity of the cleaved and active form of caspase-3 (Fig. 4A). Quantification of the intensities of the bands and statistical analyses showed that $\mathrm{As}_{2} \mathrm{O}_{3}$ treatment increased the activated caspase-3 significantly (Fig. 4B). Collectively, these data demonstrate that $\mathrm{As}_{2} \mathrm{O}_{3}$ inhibits Raji cell growth by inducing $\mathrm{G} 2 / \mathrm{M}$ arrest, eventually leading to caspase-dependent apoptotic cell death.

3-MA reverses the inhibition of cell proliferation and apoptosis induced by $\mathrm{As}_{2} \mathrm{O}_{3}$. 3-MA is a specific inhibitor of PI3K activity and one of the most widely used inhibitors of the initial phase of autophagy (5). We pre-treated Raji cells with 3-MA $(4 \mathrm{mmol} / \mathrm{l})$ for $4 \mathrm{~h}$, then different concentrations of $\mathrm{As}_{2} \mathrm{O}_{3}$ were added into the pre-treated cells. Compared with the $\mathrm{As}_{2} \mathrm{O}_{3}$ alone group, the $\mathrm{IC}_{50}$ value $(\mu \mathrm{mol} / \mathrm{l})$ at 24,48 and $72 \mathrm{~h}$ was increased to $4.85 \pm 0.24,2.22 \pm 0.15$ and $1.65 \pm 0.22$, increased by $38.2,41.4$ and $60.2 \%$, respectively (Fig. 1B). After treating Raji cells with 3-MA (4 mmol/l) and $\mathrm{As}_{2} \mathrm{O}_{3}(3 \mu \mathrm{mol} / \mathrm{l})$, the apoptotic ratio decreased from 23.5 to $18.1 \%(24 \mathrm{~h})$ and from 40.8 to $29.3 \%$ ( $48 \mathrm{~h})(\mathrm{P}<0.05)$, compared with the $\mathrm{As}_{2} \mathrm{O}_{3}$ alone group (Fig. 2). 3-MA also alleviated the G2/M arrest caused by $\mathrm{As}_{2} \mathrm{O}_{3}$ and the percentage of cells in the $\mathrm{G} 2 / \mathrm{M}$ phase decreased from 26.4 to $10.5 \%$, accompanied by an increase of the cells in the G0/G1 phase from 36.3 to $53.2 \%$ (Fig. 3). Meanwhile, the expression of caspase-3 protein (Fig. 4) markedly decreased in the combined treatment group. These results showed that 3-MA reduced the inhibition of cell proliferation and apoptosis induced by $\mathrm{As}_{2} \mathrm{O}_{3}$.

$\mathrm{As}_{2} \mathrm{O}_{3}$-induced autophagy in Raji cells is inhibited by 3-MA. To assess the autophagic activity in the Raji cells after being treated with $3 \mu \mathrm{mol} / 1 \mathrm{As}_{2} \mathrm{O}_{3}$, we observed the formation of autophagosomes using the traditional method transmission electron microscope and the fluorescence intensity of MDC was detected by fluorescence microscope. The number of autophagosomes and MDC-positive fluorescent points in the $\mathrm{As}_{2} \mathrm{O}_{3}$-treated cells was much higher than in the untreated cells and in some cells the autophagic vacuoles and apoptotic changes co-existed. However, the addition of 3-MA (4 mmol/l) 

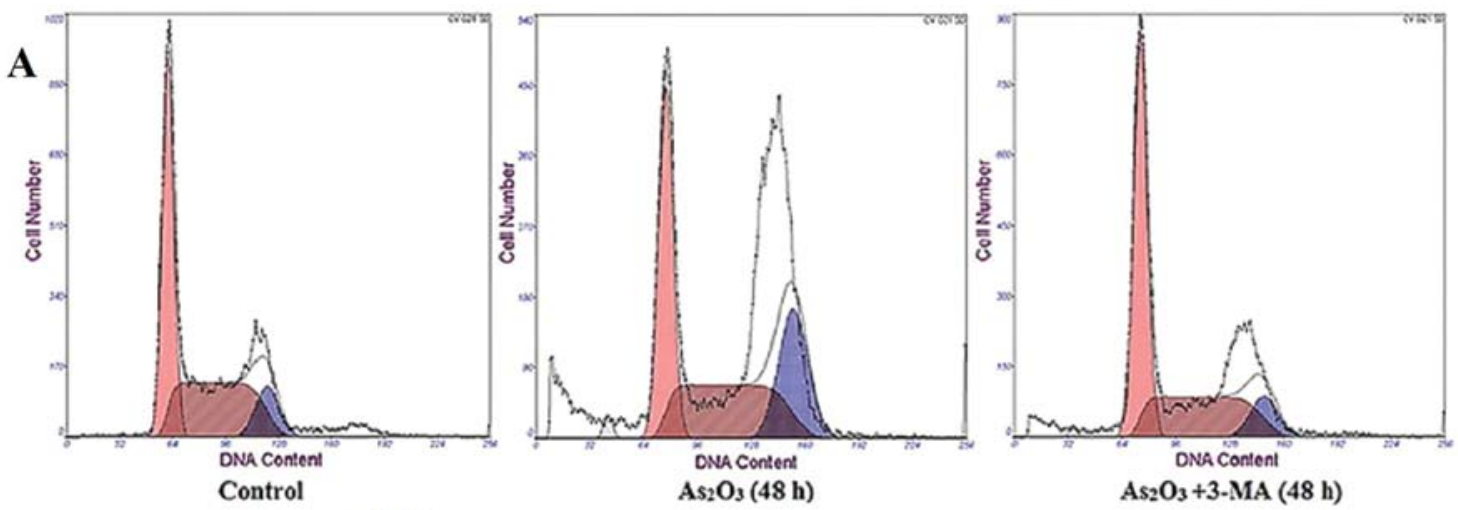

B

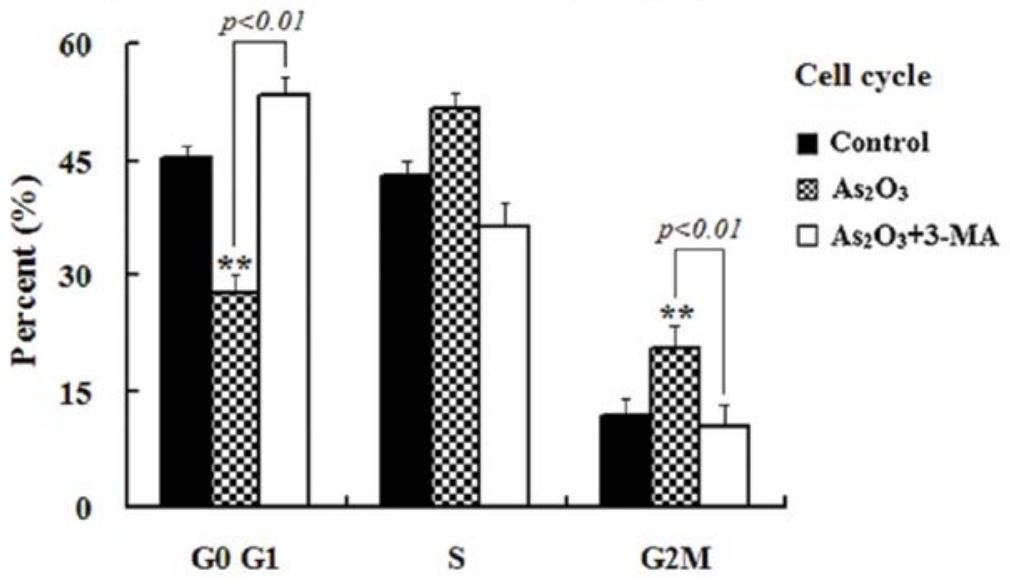

Figure 3. Effect of 3-MA on cell-cycle arrest in Raji cells induced by $\mathrm{As}_{2} \mathrm{O}_{3}$. (A) Diagram of cell cycle analyzed by flow cytometry. (B) Histogram of cell cycle. ${ }^{*} \mathrm{P}<0.05 ;{ }^{* *} \mathrm{P}<0.01$ compared to control. 3-MA, 3-methyladenine.

$\mathbf{A}$

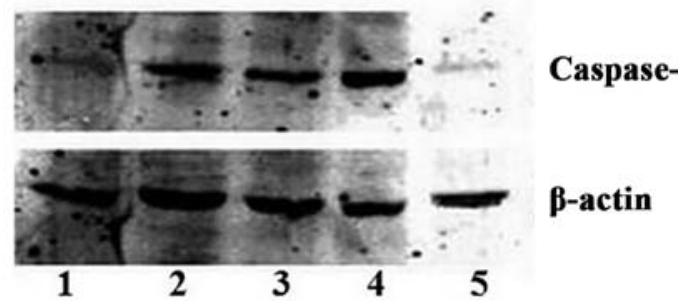

B

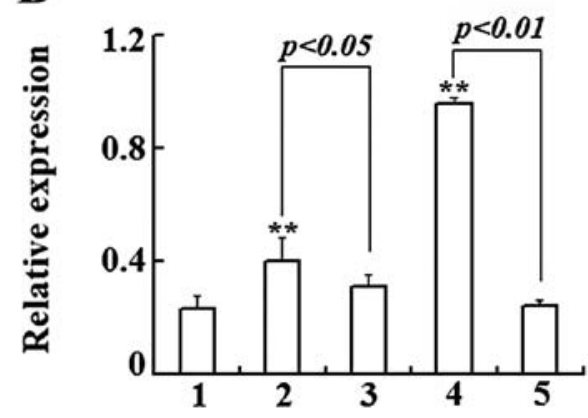

Figure 4. The expression of caspase- 3 protein in Raji cells induced by: lane $1,0 \mu \mathrm{mol} / 1 \mathrm{As}_{2} \mathrm{O}_{3}$; lane 2, $3 \mu \mathrm{mol} / 1 \mathrm{As}_{2} \mathrm{O}_{3}$ for $24 \mathrm{~h}$; lane $3,3 \mu \mathrm{mol} / 1$ $\mathrm{As}_{2} \mathrm{O}_{3}+3-\mathrm{MA}$ for $24 \mathrm{~h}$; lane $4,3 \mu \mathrm{mol} / 1 \mathrm{As}_{2} \mathrm{O}_{3}$ for $48 \mathrm{~h}$; and lane 5, $3 \mu \mathrm{mol} / 1$ $\mathrm{As}_{2} \mathrm{O}_{3}+3-\mathrm{MA}$ for $48 \mathrm{~h}$. (A) The changes of caspase-3 protein levels were examined by western blotting. (B) Histogram of the average infrared fluorescence intensity of the caspase-3 protein bands. ${ }^{* *} \mathrm{P}<0.01$, compared with the control group. 3-MA, 3-methyladenine. prior to $\mathrm{As}_{2} \mathrm{O}_{3}(3 \mu \mathrm{mol} / \mathrm{l})$ treatment decreased the number of autophagosomes and the fluorescence intensity of MDC (Fig. 5).

In order to distinguish whether autophagosome accumulation was due to autophagy induction or a block in downstream steps, we detected the expression level of P62, an autophagy substrate that can be used to monitor autophagic flux, and the expression levels of P62 inversely correlated with autophagic activity (14). Our research showed that after Raji cells were treated with $3 \mu \mathrm{mol} / 1 \mathrm{As}_{2} \mathrm{O}_{3}$ for 24 and $48 \mathrm{~h}$, the level of P62 protein was obviously decreased. On the contrary, 3-MA increased the total level of P62 protein (Fig. 6A and B). The results provide evidence that the autophagosome accumulation was due to autophagy induction instead of a block in downstream steps.

To further confirm the above result, we examined expression of LC3-II (microtubule-associated protein 1, light chain 3, in its conjugated form) by western blotting, since LC3-II is widely used as a specific marker of autophagic activity $(15,16)$. The results (Fig. 6C and D) showed that $\mathrm{As}_{2} \mathrm{O}_{3}(3 \mu \mathrm{mol} / \mathrm{l})$ treatment could result in the upregulation of LC3-I and a considerable portion of LC3-I was converted into LC3-II. However, after Raji cells were co-treated with $\mathrm{As}_{2} \mathrm{O}_{3}$ and 3-MA, the expression of LC3-I-II was significantly downregulated and the conversion of LC3-II from LC3-I was also inhibited.

Interaction of Beclin-1 and Bcl-2 mediates the crosstalk between apoptosis and autophagy induced by $\mathrm{As}_{2} \mathrm{O}_{3}$. To 


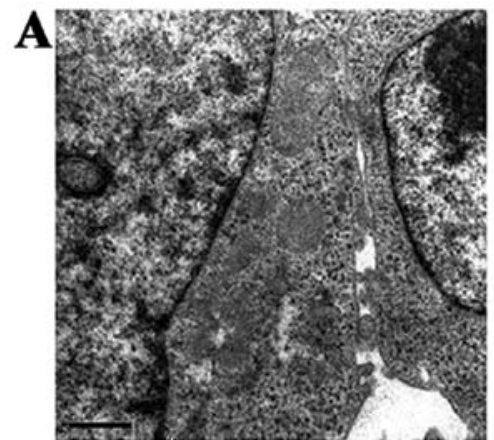

Control

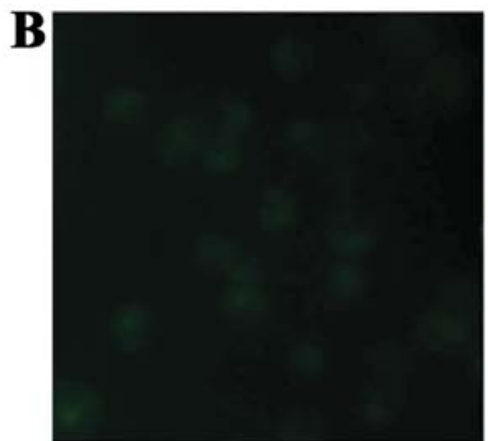

Control

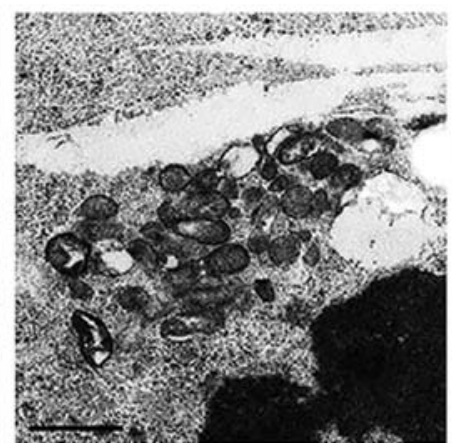

$\mathrm{As}_{2} \mathrm{O}_{3}(48 \mathrm{~h})$

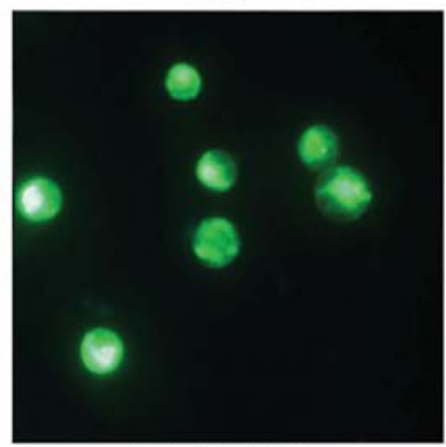

$\mathrm{As}_{2} \mathrm{O}_{3}(48 \mathrm{~h})$

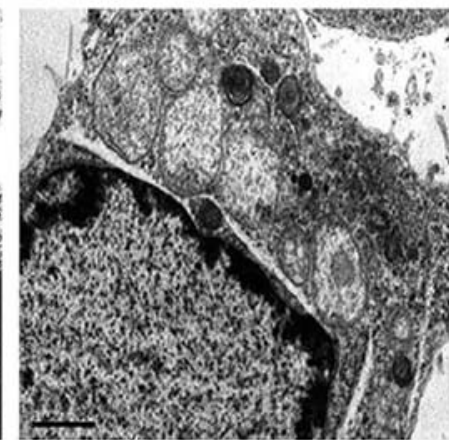

$\mathrm{As}_{2} \mathrm{O}_{3}+3-\mathrm{MA}(48 \mathrm{~h})$

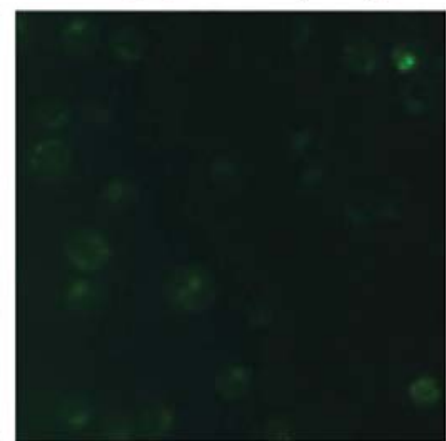

$\mathrm{As}_{2} \mathrm{O}_{3}+3-\mathrm{MA}(48 \mathrm{~h})$

Figure 5. Detection of autophagosome. (A) The formation of autophagosomes (original magnification x30,000), the arrow indicates the autophagosome. (B) The fluorescence intensity of MDC (original magnification x1,000). MDC, monodansylcadaverine.

$\mathbf{A}$

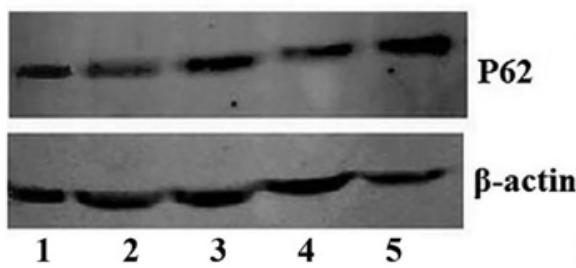

C

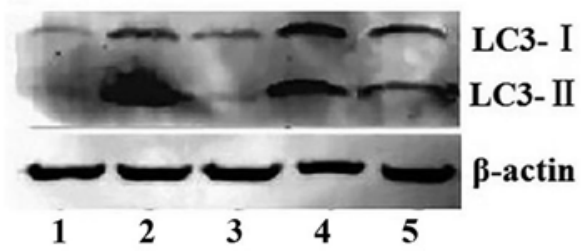

B

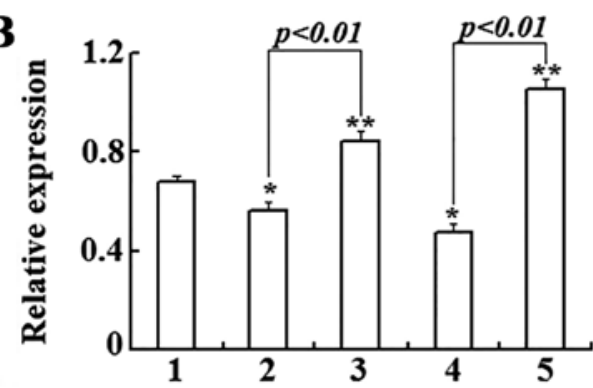

D

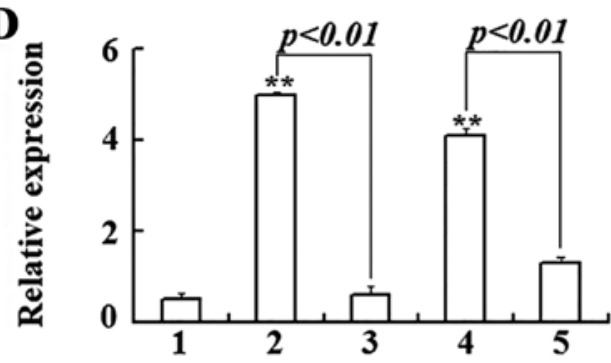

Figure 6. The expression of P62 and LC3 in Raji cells induced by: lane 1, $0 \mu \mathrm{mol} / 1 \mathrm{As}_{2} \mathrm{O}_{3}$; lane $2,3 \mu \mathrm{mol} / 1 \mathrm{As} \mathrm{O}_{3}$ for $24 \mathrm{~h}$; lane $3,3 \mu \mathrm{mol} / 1 \mathrm{As} \mathrm{O}_{3}+3-\mathrm{MA}$ for $24 \mathrm{~h}$; lane 4, $3 \mu \mathrm{mol} / 1 \mathrm{As}_{2} \mathrm{O}_{3}$ for $48 \mathrm{~h}$; and lane 5, $3 \mu \mathrm{mol} / 1 \mathrm{As}_{2} \mathrm{O}_{3}+3-\mathrm{MA}$ for $48 \mathrm{~h}$. (A) The levels of P62 protein. (B) The average fluorescence intensity of P62 protein bands. (C) The expression of LC3-I, II protein. (D) Histogram of the average fluorescence intensity of LC3-II protein bands. As $\mathrm{O}_{3}$ treatment significantly upregulated the level of LC3-II and the action was clearly inhibited by $3-\mathrm{MA}$. * $\mathrm{P}<0.05 ;{ }^{* *} \mathrm{P}<0.01$ compared with control group.

explore the necessary connection between autophagy and apoptosis, we detected the expression levels of Beclin-1 and Bcl-2 genes using western blotting and real-time RT-PCR assay to prove the interaction of Beclin-1 and Bcl-2 in part mediated the $\mathrm{As}_{2} \mathrm{O}_{3}$-induced apoptotic and autophagic cell death in Raji cells. After treatment with $3 \mu \mathrm{mol} / 1 \mathrm{As}_{2} \mathrm{O}_{3}$ for 24 and $48 \mathrm{~h}$, the expression of Beclin-1 protein was increased by 2.2- and 1.46-fold and the Beclin-1 mRNA was increased by
2.38- and 2.19-fold respectively and these actions were clearly inhibited by addition of 3-MA (Fig. 7A-D). On the contrary, Raji cells treated with $\mathrm{As}_{2} \mathrm{O}_{3}$ exhibited a time-dependent decrease in both Bcl-2 mRNA and protein expression, but 3-MA upregulated their expression of both Bcl-2 mRNA and proteins (Fig. 7E-H). The enhanced expression of Beclin-1 was in parallel with suppression of $\mathrm{Bcl}-2$ during $\mathrm{As}_{2} \mathrm{O}_{3}$-induced death in Raji cells. 


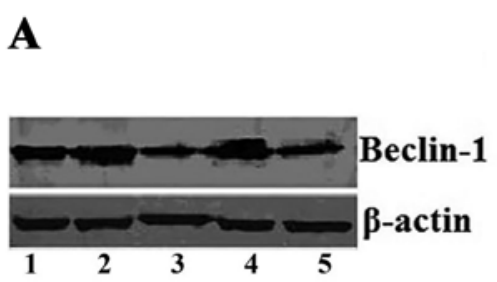

$\mathbf{C}$

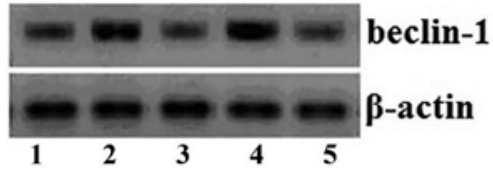

$\mathbf{E}$
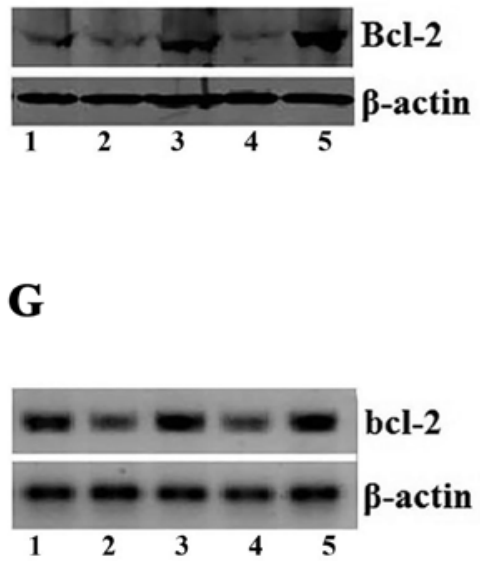
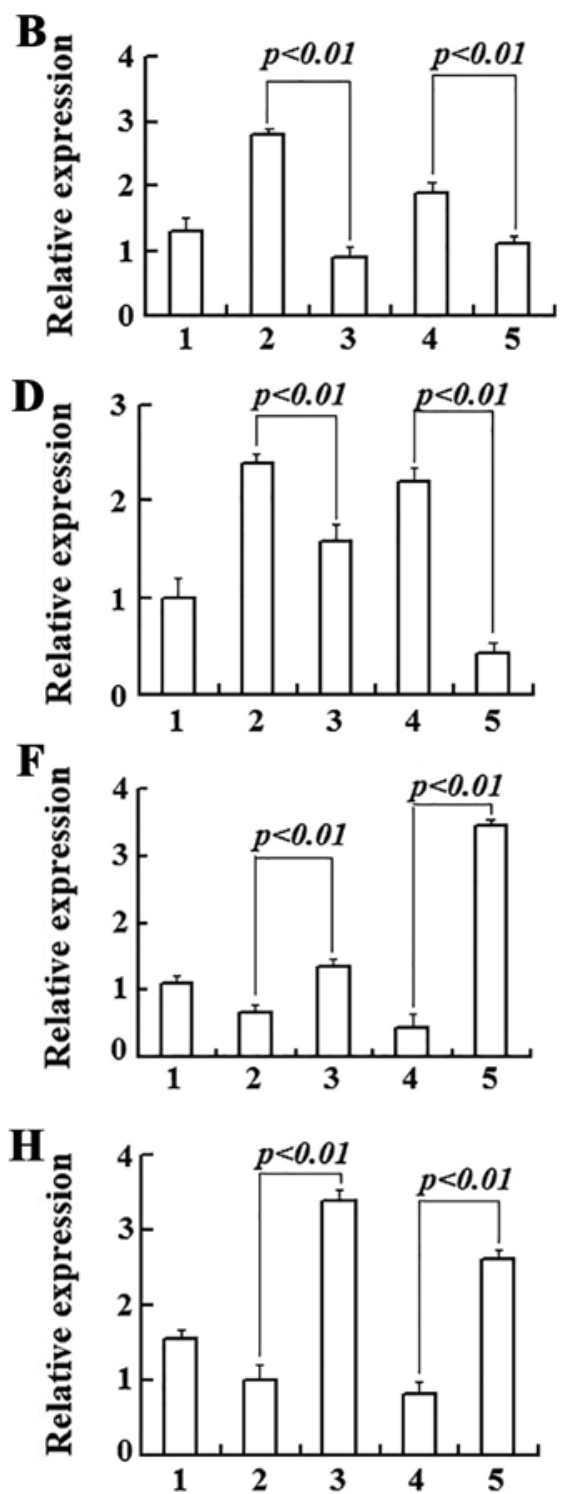

Figure 7. The dynamical variation of Beclin-1 and Bcl-2 in Raji cells induced by: lane $1,0 \mu \mathrm{mol} / 1 \mathrm{As}_{2} \mathrm{O}_{3}$; lane $2,3 \mu \mathrm{mol} / 1 \mathrm{As}_{2} \mathrm{O}_{3}$ for $24 \mathrm{~h}$; lane $3,3 \mu \mathrm{mol} / 1$ $\mathrm{As}_{2} \mathrm{O}_{3}+3$-MA for $24 \mathrm{~h}$; lane 4, $3 \mu \mathrm{mol} / 1 \mathrm{As}_{2} \mathrm{O}_{3}$ for $48 \mathrm{~h}$; and lane 5, $3 \mu \mathrm{mol} / 1 \mathrm{As}_{2} \mathrm{O}_{3}+3$-MA for $48 \mathrm{~h}$. (A and E) The expressions of Beclin-1 and Bcl-2 protein. (B and F) The average infrared fluorescence intensity of Beclin-1 and Bcl-2 protein bands. (C and G) The real-time PCR amplification products of beclin-1 and bcl-2 were observed by agarose gel electrophoresis. (D and H) Real-time RT-PCR assay evaluated the amounts of beclin-1 and bcl-2 mRNA. 3-MA, 3-methyladenine.

\section{Discussion}

$\mathrm{As}_{2} \mathrm{O}_{3}$ is a clinically highly relevant anticancer drug used for the treatment of various cancer, especially leukemia. The mechanisms of $\mathrm{As}_{2} \mathrm{O}_{3}$-induced cell death have been extensively investigated. Apoptosis is considered to be one of the important mechanisms $(12,17)$. However, in recent years, the role of autophagy in cancer therapy has also received increasing attention from researchers, and many studies have shown that autophagy is readily induced in response to certain stressful stimuli, such as metabolic stress $(18,19)$ and exposure to anticancer drugs $(20,21)$. Hence, it is believed that autophagy may play an important role in tumorigenesis and cancer therapy. However, the fundamental question, whether autophagy promotes cancer cell death or protects them from unfavorable conditions, remains controversial. It is certainly an intricate target for cancer therapy (22).
In our study, we demonstrated that $\mathrm{As}_{2} \mathrm{O}_{3}$ inhibited both proliferation and viability of Raji cells in a dose- and timedependent manner. Raji cells treated with $\mathrm{As}_{2} \mathrm{O}_{3}$ underwent apoptosis and cell cycle arrest. Moreover, $\mathrm{As}_{2} \mathrm{O}_{3}$ promoted the formation of autophagic vacuoles and the conversion of soluble LC3-I to lipid bound LC3-II, as well as increased the degradation of autophagy substrate $\mathrm{P} 62$ protein. The autophagic vacuoles and apoptotic changes always co-existed in the same cells. 3-MA is one of the most widely used pharmacologic inhibitors of autophagy; it can block class III phosphatidylinositol 3-kinase (PI3K) activity, thereby reducing the number of autophagic vacuoles and the conversion of LC3-I to LC3-II. Furthermore, 3-MA also alleviated the proliferation inhibition, apoptosis and $\mathrm{G} 2 / \mathrm{M}$ phase arrest in Raji cells induced by $\mathrm{As}_{2} \mathrm{O}_{3}$. In addition, 3-MA decreased the upregulation of caspase- 3 protein caused by $\mathrm{As}_{2} \mathrm{O}_{3}$. These results provide evidence that the Raji cell death induced by 
$\mathrm{As}_{2} \mathrm{O}_{3}$ shared characteristics of both autophagic and apoptotic cell death.

Bcl-2 proto-oncogene is a well-known anti-apoptotic mediator. However, its roles in inhibiting autophagy have attracted increasing attention from researchers. Bcl-2 is welldocumented to inhibit autophagy via the interaction with Beclin-1 (23,24). Akar et al (25) reported that RNAi knockdown of Bcl-2 induced the autophagy and apoptosis in MCF-7 breast cancer cells. Saeki et al (26) found that Bcl-2 silencing by antisense RNA induced the autophagy-dependent cell death in human leukemia HL-60 cells. The dual role of Bcl-2 in inhibiting both apoptosis and autophagic-associated cell death makes this protein a potential chemotherapeutic target. Beclin-1, a Bcl-2 homology 3 (BH3) domain only protein, is essential for the double-membrane autophagosome formation, which is required during the initial steps of autophagy $(27,28)$. Beclin-1 recruits key autophagic proteins to a pre-autophagosomal structure, thereby forming the core complex consisting of Beclin-1, Vps15 and Vps34 (29-31). In addition, Beclin-1 is a key determining factor with regard to whether cells undergo autophagy or apoptosis. Nutrient deprivation or other stress conditions result in the activation of the stress-induced MAPK JNK, which phosphorylates three residues in the regulatory loop of Bcl-2, disrupting its interaction with Beclin-1 to permit autophagy (32). In our study, we found that $\mathrm{As}_{2} \mathrm{O}_{3}$ significantly enhanced the expression of Beclin-1 protein and its mRNA; on the contrary, the expression of $\mathrm{Bcl}-2$ protein and the level of Bcl-2 mRNA were clearly downregulated and these effects were antagonized by 3-MA. These findings indicate that both apoptotic and autophagic pathways are involved in $\mathrm{As}_{2} \mathrm{O}_{3}$-induced death in Burkitt's lymphoma cells and the co-action or crosstalk of Beclin-1 and Bcl-2 may play a key role in coordinating the relationship between autophagic cell death and apoptosis. Therefore, $\mathrm{As}_{2} \mathrm{O}_{3}$ may act as a joint activator of apoptosis and autophagy and regulation of autophagic activity may be a promising therapy for patients with Burkitt's lymphoma.

\section{Acknowledgements}

This study was supported by the Fundamental Research Funds for the Central Universities from Northwest University for Nationalities, China (no. zyz2011094) and Science and Technology Planning Project from Chengguan District, Lanzhou, Gansu Province, China (no. 2013-7-17).

\section{References}

1. Levine B and Kroemer G: Autophagy in the pathogenesis of disease. Cell 132: 27-42, 2008.

2. Debnath J, Baehrecke EH and Kroemer G: Does autophagy contribute to cell death? Autophagy 1: 66-74, 2005.

3. Kroemer G and Levine B: Autophagic cell death: the story of a misnomer. Nat Rev Mol Cell Biol 9: 1004-1010, 2008.

4. Chen L, Liu Q, Huang Z, et al: Tripchlorolide induces cell death in lung cancer cells by autophagy. Int J Oncol 40: 1066-1070, 2012.

5. Cho KH, Park JH, Kwon KB, et al: Autophagy induction by low-dose cisplatin: The role of p53 in autophagy. Oncol Rep 31: 248-254, 2014

6. Gordy $\mathrm{C}$ and He YW: The crosstalk between autophagy and apoptosis: where does this lead? Protein Cell 3: 17-27, 2012.

7. Qian W, Liu J, Jin J, Ni W and Xu W: Arsenic trioxide induces not only apoptosis but also autophagic cell death in leukemia cell lines via up-regulation of Beclin-1. Leuk Res 31: 329-339, 2007.
8. Chen GQ, Shi XG and Tang W: Use of arsenic trioxide $\left(\mathrm{As}_{2} \mathrm{O}_{3}\right)$ in the treatment of acute promyelocytic leukemia (APL): $\mathrm{I}_{2} \mathrm{As}_{2} \mathrm{O}_{3}$ exerts dose-dependent dual effects on APL cells. Blood 89: 3345-3353, 1997.

9. Li YM and Broome JD: Arsenic targets tubulins to induce apoptosis in myeloid leukemia cells. Cancer Res 59: 776-780, 1999.

10. Hu XM, Hirano T and Oka K: Arsenic trioxide induces apoptosis equally in T lymphoblastoid leukemia MOLT-4 cells and P-gp-expressing daunorubicin-resistant MOLT-4 cells. Cancer Chemother Pharmacol 51: 119-126, 2003.

11. Rousselot P, Labaume S, Marolleau JP, et al: Arsenic trioxide and melarsoprol induce apoptosis in plasma cell lines and in plasma cells from myeloma patients. Cancer Res 59: 1041-1048, 1999.

12. Chen J, Wei H, Xie B, Wang B and Cheng J: Endoplasmic reticulum stress contributes to arsenic trioxide-induced apoptosis in drug-sensitive and -resistant leukemia cells. Leuk Res 36: 1526-1535, 2012.

13. Biederbick A, Kern HF and Elsasser HP: Monodansylcadaverine (MDC) is a specific in vivo marker for autophagic vacuoles. Eur J Cell Biol 66: 3-14, 1995.

14. Bjorkoy G, Lamark T, Brech A, Outzen H, Perander M, et al: p62/SQSTM1 forms protein aggregates degraded by autophagy and has a protective effect on huntingtin-induced cell death. J Cell Biol 171: 603-614, 2005.

15. Tang Z, Ni L, Javidiparsijani S, et al: Enhanced liver autophagic activity improves survival of septic mice lacking surfactant proteins A and D. Tohoku J Exp Med 231: 127-138, 2013.

16. Galluzzi L, Aaronson SA, Abrams J, et al: Guidelines for the use and interpretation of assays for monitoring cell death in higher eukaryotes. Cell Death Differ 16: 1093-1107, 2009.

17. Zhang W, Ohnishi K, Shigeno K, et al: The induction of apoptosis and cell cycle arrest by arsenic trioxide in lymphoid neoplasms. Leukemia 12: 1383-1391, 1998.

18. Degenhardt K, Mathew R, Beaudoin B and Bray K: Autophagy promotes tumor cell survival and restricts necrosis, inflammation, and tumorigenesis. Cancer Cell 10: 51-64, 2006.

19. Karantza-Wadsworth V, Patel S, Kravchuk O, Chen G, et al: Autophagy mitigates metabolic stress and genome damage in mammary tumorigenesis. Genes Dev 21: 1621-1635, 2007.

20. Cheng J, Wei HL, Chen J and Xie B: Antitumor effect of arsenic trioxide in human K562 and K562/ADM cells by autophagy. Toxicol Mech Methods 22: 512-519, 2012.

21. Pan J, Chen B, Su CH, Zhao R, Xu ZX, et al: Autophagy induced by farnesyltransferase inhibitors in cancer cells. Cancer Biol Ther 7: 1679-1684, 2008.

22. de-Bruin EC and Medema JP: Apoptosis and non-apoptotic death in cancer development and treatment response. Cancer Treat Rev 34: 737-749, 2008.

23. Shimizu S, Kanaseki T, Mizushima N, et al: Role of Bcl-2 family proteins in a non-apoptotic programmed cell death dependent on autophagy genes. Nat Cell Biol 6: 1221-1228, 2004.

24. Pattingre S, Tassa A and Qu X: Bcl-2 antiapoptotic proteins inhibit Beclin 1-dependent autophagy. Cell 122: 927-939, 2005.

25. Akar U, Chaves-Reyez A, Barria M, Tari A, et al: Silencing of Bcl-2 expression by small interfering RNA induces autophagic cell death in MCF-7 breast cancer cells. Autophagy 4: 669-679, 2008.

26. Saeki K, Yuo A, Okuma E, et al: Bcl-2 down-regulation causes autophagy in a caspase-independent manner in human leukemic HL60 cells. Cell Death Differ 7: 1263-1269, 2000.

27. Salminen A, Kaarniranta K and Kauppinen A: Beclin 1 interactome controls the between apoptosis, autophagy and inflammasome activation: impact on the aging process. Ageing Res Rev 12: 520-534, 2013.

28. Cao Y and Klionsky DJ: Physiological functions of Atg6/Beclin 1: a unique autophagy-related protein. Cell Res 17: 839-849, 2007.

29. Oberstein A, Jeffrey PD and Shi Y: Crystal structure of the Bcl-XL-Beclin 1 peptide complex: Beclin 1 is a novel BH3-only protein. J Biol Chem 282: 13123-13132, 2007.

30. Takahashi Y, Coppola D, Matsushita N, et al: Bif-1 interacts with Beclin 1 through UVRAG and regulates autophagy and tumorigenesis. Nat Cell Biol 9: 1142-1151, 2007.

31. Liang XH, Kleeman LK, Jiang HH, Gordon G, et al: Protection against fatal Sindbis virus encephalitis by beclin, a novel Bcl-2-interacting protein. J Virol 72: 8586-8596, 1998.

32. Erlich S, Mizrachy L, Segev O, Lindenboim L, et al: Differential interactions between Beclin 1 and Bcl-2 family members. Autophagy 3: 561-568, 2007. 